\title{
The Impact of Mission and Involvement on Employees' Performance in Hotel Sector of Pakistan
}

\author{
* Mohammad Hanif Khan, Assistant Professor \\ ** Altaf Hussain, Assistant Professor \\ *** Muhammad Asad Khan, PhD Scholar
}

\begin{abstract}
This research aims to examine the impact of mission and involvement on employees' performance. This research work aimed to check the influence of mission and involvement which are two traits of the culture of the organization over employees' performance in the hotel sector of Pakistan. 108 employees were sampled out of 549 employees. To collect data from respondents, the questionnaire was used to have a Likert Scale type. To analyze data, regression analysis was used. The study found that there is a significant impact of mission and involvement on employees' performance. This study recommends that there should be a clear mission that gives direction to the work. Goals set must be realistic and there should be a widespread agreement about goals. This work also recommends that always keep employees involved in business planning. Teamwork needs to be instilled rather than exercising hierarchy. Delegation of authority will make them more responsible. Future directions are also specified.
\end{abstract}

Keywords: Mission, involvement, employee performance, hospitality sector

\section{Introduction}

Organizational Culture is the combination of beliefs, norms and values which exist in the organization. Organizations are generally differentiated based on these distinctive features (Berg \& Wilderom, 2004). It is the whole construct of morals, customs, actions, attitudes and customs which makes the organization a unique entity. To take it further organizational culture covers all activities which occur in the establishment and reactions of employees towards every situation (Schultz \& Ravasi, 2006). It is the totality of all behaviors which new member of the establishment adopts. Hence, organizational culture explains the pattern of your dealing with all those who are associated with your business directly or indirectly like clients, colleagues, suppliers and the rest. (Schrodt, 2002). The research of Kotter and Haskett (1992), Schein, (1992) and Deal and Kennedy, (1982) have elaborated it further and opined that all organizations have a distinctive and separate culture. They have subcultures within the umbrella of that culture within which different teams are represented.

Organizational culture has four traits; mission, involvement, adaptability and consistency developed by Dr. Denison (1990). The focus of this research is on mission and involvement only. In this study we will discuss that how mission; which is the intent and long term direction of an organization and involvement; which is the creation of a sense of ownership and shared responsibility throughout the organization can impact employees' performance.

The mission of the organization is defined as the reason for the organization's existence; the long term intent or direction of the organization. The understanding of employees what is the strategic planning done by the management. The employees should feel that their day-to-day job will work for the organization to achieve their short and long term objectives. Does the working of employees contribute something to the organization's vision? Do they feel that their job fits in the game plan of the organization? Do employees share common objectives to work for the desired future of the organization (Denison \& Mishra 1995)? The mission should motivate the employees. The clear mission can make the staff intent clearer towards the objectives of the organization. Mission is always based on the resources and distinctive competencies of the organization. A sound chalked out mission

\footnotetext{
* Department of Tourism and Hotel Management, University of Malakand, Khyber Pakhtunkhwa, Pakistan Email: hanifyousafzai@uom.edu.pk

** Department of Commerce and Management Sciences, University of Malakand, Khyber Pakhtunkhwa, Pakistan Email: altafhussain@uom.edu.pk

*** Universiti Tun Hussein Onn (UTHM) Malaysia Email: asadkhanbte06@ gmail.com
} 
delivers the employees a shared sense of direction, purpose, and opportunity. The mission should stress on those policies which the company wants to exercise and honor (Dessler, 2009).

Involvement is to create a sense of shared responsibility and ownership throughout the organization. Employees may feel the part of the management and have a fair share in the decisionmaking process. Employees feel that they are informed and involved in the work they perform in the organization. They do have a reasonable share in their work assignments and have a say in their work design. They do have the feeling that their work will contribute a huge amount to their organization. If they perform well, it will have a direct impact on the performance of their organization. If they poorly perform, the organization performance will also suffer. They are not going to perform their work independently but will work as a responsible team member. Their work will contribute to strengthening the team formation and their work as a team. They all feel that they are responsible for achieving organizational objectives and goals. They feel responsible for not achieving the goals and objectives of the organization. They make themselves accountable for the work they do to achieve common goals. The employees do feel that their organization is investing in them for their skills' upgradation. They are getting the required expertise through continuous training and development by the organization. They are continuously investing in strengthening their bench strength. They are making substitutes for their employees within that workforce. They are regularly assessing their strengths and expertise to stay ahead in the competition and to compete in the future as well. They do work on the employees keeping in view present they present and future competitive edge over competitors (Dennison \& Mishra 1995).

Employees' performance is defined in simple words as the total behavior of employees at work premises (Jex, 2002). Though, it seems a bit imprecise definition. The specific amount of employees' behavior at work does not relate to his job performance. More commonly employees' performance refers to how well an employee performs while performing his job duties (Berghe \& Hyung, 2011). Performance is the product of work done by an employee or group of employees in fulfilling their duties and at the same time the outcome must be aligned with work principles. The work performed necessarily to agree with moral practices and law will also support it (Pravirosantoso \& Suryadi, 2000). Employees' performance is to maintain quality and quantity in fulfilling the job assigned to an employee (Mangkunegara, 2005). Performance is the result after a job is completed. It shows the magnitude of the achievement of each position and contribution toward organizational demands, expectations, or principles for designated official roles. The research work of Kato and Prasetya (2011) states that, performance is the outcome of hard work with the proficiency of staff members who outshine in some position. Furthermore, performance is the result articulated in quantity, quality and impact one creates to his job. The higher is the outcome concerning quality and quantity; the trajectory of performance will also be on an upward side in the organization (Sun, 2001). According to Whitmore (1997) performance is considered the engagements and the exhibition of capability and talent. To take it further, performance is the usefulness, productivity, and value of employees' overall work outcomes (Hsu, 2005). The research work of Gibson et al. (1995) elaborated that a person's performance is generally the result of achievements he achieves concerning his location in the organization. Anderson and William (1991) study revealed that person performance is the shared product of determination, capability, and insight of tasks.

\section{Organizational Culture Impact on Performance of Employees}

The study conducted by Paschal and Nizam (2016) concludes that employees' performance is largely influenced by the culture prevailing in the organization. They have conducted their research work in the Telecommunication industry in Singapore. The study work of Ojo (2009) carried out in the banking industry of Nigeria, revealed that organizational culture has got enormous importance for each organization and has a significant positive influence on the performance of the workforce. Organizations having strong cultures always put their employees in a strong organization's system and thus resulting in performance enhancement of their workers. Weak organizational culture get their employees underperform. Standards of productivity are closely linked with Organizational culture. Companies that hold solid organizational culture, the output of workers remain high but in fragile culture it trickles down. According to the research work Kandula (2006), good performance is the result of a strong culture. The uniform policies do not produce uniform results due to the difference in organizational culture; though the location and industry may remain the same. He opined further that 
solid and strong organizational culture gets the best from the normal worker and fragile and weaker culture blurs the proficiencies and performance of an outstanding worker. Organizational culture affects performance positively with significance revealed by Ehtesham et al. (2011). They also elaborated that organizational culture has a strong relationship with organizational performance. The working and performance of an employee have a close connection with organizational culture. Organizations that have a strong culture, the performance of organizational members will be good. Low performance is exhibited in a weak culture. The research work of Ahmad (2012) which he conducted in the higher education sector in Pakistan also confirmed that organizational culture does have a strong positive influence on the performance. The research work further explained that organizational culture is a significant phenomenon of an organization as it can and it does move employees', attitudes, performance behaviors, values and motivation. Organizational cultures do affect the complete buildup of employees. It stimulates the employees; get optimistic changes in their approach, conduct and beliefs. The study of Abukar and Mohamed (2013) carried out in Somalia's Mogadishu universities highlights a positive association between the culture of the organization and the performance of employees. This relationship remains positive. This projects that when one variable rises the other variable will also raise and if one variable is on the downside, the other will also behave in the same downward direction. Zamir and Nazir (2015) work testifies the result that the relationship between the two variables is also significant positive. The answers of both genders were measured which resulted in the culture of the organization has a positive and substantial association with performances. The research endeavor of Olughor (2014) performed in the banking sector of Nigeria also discovered that the culture of the organization makes way for the performance of the establishment. The enhanced establishment's performance and working are built on a solid culture of organization.

Studies conducted by Ghani (2006) and Raka (2003) revealed that no relationship is witnessed between the culture of the organization and the performance of employees. Both have nothing to do with each other. The research work of Solimun, Syauta and Troena (2012) also denies the same relationship by highlighting that employees' performance is not the outcome of strong organizational culture. The same relationship will exist when there is the mediating effect of job satisfaction. It also clarifies that the solid culture of the organization does not bring any significant changes in employees' performance.

\section{Methodology}

It was descriptive research; data were collected from the respondents through the questionnaire. Total 09 hotels were randomly selected for the study from large, medium and small hotels. The total numbers of employees were 549. In the first phase, the hotel industry in Peshawar city, the capital city of Khyber Pakhtunkhwa, Pakistan, was divided into three strata (large, medium and small) based on the size of the hotel. To give representation to each strata, in the second stage the researchers selected two large, three medium and four small hotels wherein the researchers have collected data from managerial hierarchy which consists of all three types top, middle and lower management. The proportionate sampling method was used in the third stage for giving appropriate representation to every stratum based on their quantity of employees. $47 \%$ of respondents were taken from large; the size $31 \%$ taken from medium while the portion of the small hotels were $22 \%$ respondents. Daniel Dennison (2000) tool was adapted by the researchers and used with minor changes for its application and compatibility with the area for assessing organizational culture. The researchers developed 36 items tool for measurement. The job performance instrument consisted of 4 items taken from the study of William and Anderson (1991) was employed in the study. Both the instruments were found valid and reliable. As per research ethics pilot testing is necessary so it was done to ensure the reliability of the tool used. Cronbach Alpha value was inquired, the value of which was .857 which was quite acceptable. The impact of variables was measured using Regression analysis. 
Data Analysis and Results

Table 1: Model of Organizational Culture and Performance of Employees

Model of Organizational Culture \& Performance of Employees

\begin{tabular}{lcrccr}
\hline & Unstandzed Coefnt & Standard Coefnt & t & Sig \\
Model & $\mathrm{B}$ & Std. Eror & Beta & 6.071 & .000 \\
$\begin{array}{l}\text { Constant) } \\
\text { Organizational }\end{array}$ & 8.705 & 1.434 & & & \\
Culture & .041 & .011 & .453 & 3.665 & .001 \\
\hline
\end{tabular}

Outcome Variable: Performance of Employees

Table 1 reflects that $p<0.05$ so this testifies that the effect is significant. The impact of change variable organizational culture is significant on outcome variable employees' performance.

Table2: Model of Mission and Performance of Employees

Model of Mission and Performance of Employees

\begin{tabular}{lccccc}
\hline & \multicolumn{2}{c}{ Unstandzed Coefnt } & Standard Coefnt & t & Sig \\
Model & $\mathrm{B}$ & Std. Eror & Beta & & \\
(Constant) & 10.802 & 1.311 & & 8.231 & .000 \\
Mission & .102 & .041 & .315 & 2.405 & .019
\end{tabular}

Outcome Variable: Performance of Employees

Table 2 reflects that $\mathrm{p}<0.05$ so this testifies that the effect is significant. The impact of change variable Mission is significant on outcome variable employees' performance.

Table 3: Model of Involvement and Performance of Employees

Model of Involvement and Performance of Employees

\begin{tabular}{lccccc}
\hline & \multicolumn{2}{c}{ Unstandzed Coefnt } & Standd Coefnt & t & Sig \\
Model & $\mathrm{B}$ & Std. Eror & Beta & 12.192 & .000 \\
(Constant) & 11.564 & .948 & & 2.529 & .014 \\
Involvement & .068 & .027 & .331 & & \\
\hline
\end{tabular}

Outcome Variable: Performance of Employees

Table 3 reflects that $p<0.05$ so this testifies that the effect is significant. The impact of change variable Involvement is significant on outcome variable employees' performance.

\section{Discussion}

The objective of this research was to observe the influence of organizational culture and its two traits mission and involvement over the performance of employees. The outcomes of this study support the significant impact of the culture of the organization and its two traits mission and involvement on the performance of employees.

The results of this study are by the results of the study of Zakari, Poku, Anash and Wilberforce (2013) conducted in the banking sector in Ghana. The outcomes of this study are same as maintained by the work of Ojo (2009), carried out in Nigerian's banking sector, Ehtesham et al. (2011) study work, conducted in Pakistan's education sector and the research endeavor of Ahmad's (2012) performed in Pakistan's education sector. The outcomes of our study also take further the research work efforts of Abukar and Mohammad, (2013) undertaken in the education sector of Somalia, the study of Olughor, (2014) carried out in the financial sector in Nigeria; Nazir and Zamir, (2015) study which were conducted in Pakistan's different organizations. Rahimi, (2017) study also supports this result. All of the stated research studies confirmed that irrespective of the context, country, region or state organizational culture influences the performance of employees in a significant positive manner.

The outcomes of this work are as opposed to studies of Hamidah, Okta, Musadiq and Umar, (2015), Solimun, Syauta and Troena (2012), Ghani (2006) and Raka (2003) conducted in Indonesia's processing units of food and beverage. 


\section{Conclusions, Recommendation and Limitations}

Based on empirical evidences the culture of the organization is having a positive impact on the performance of personnel of the hotel industry of Pakistan. The study also supports that there is a positive impact of mission and involvement on employees' performance in the hotel industry of Pakistan. Data support that performance of employees is supported by strong organizational culture having a clear mission and involvement of employees.

A clear and realistic mission of an organization has positive consequences on the performance of workers. Their performance would improve if the mission is clear and realistic. Shared vision and agreement about goals also fuel performance.

Organizations need to involve all employees in the important tasks and decisions, it gives them a sense of ownership and consequently it affects their performance positively. People enjoy working in organizations where they are considered an integral part of the team. Delegation of authority also instills a sense of responsibility thus increase employees' performance.

Keep employees involved in business planning. Teamwork needs to be instilled rather than exercising hierarchy. Delegation of authority will make them more responsible. Always invest in the skills of employees through training and development. The management can use the capabilities of their employees as a competitive edge. Employees are needed to be inspired and motivated so that they can be kept engaged in their work. The most important part is team building. Everybody has to feel themselves as organ of the team.

Management style must be clear so the employees can manage their working accordingly. The practice of consistent values needs to be encouraged. The core values must be in practice. Consensus needs to be developed on difficult issues. The goals and objectives should be the common target. Management should work hard to maintain harmony and a family-like environment.

There should be a clear mission that gives direction to the work. Goals set must be realistic and there should be a widespread agreement about goals. Long run success may be highlighted without compromising on short term demands. There should be a shared vision.

For further research, it is recommended that the mediating or moderating effect can be enquired in these variables. The same relationship can be checked in other sectors and contexts. Qualitative research may be carried out and for data collection other cities may be selected. This will further clarify the relationship of variables and may give some more understanding of the phenomenon.

In this study only a quantitative data collection technique was adopted. This research work was cross-sectional, one point of time data collection was done. Only one city was chosen for data collection, though this city is one of the biggest cities in the country.

\section{References}

Ahmad, M. (2012). Impact of organizational culture on performance management practices in Pakistan, Business Intelligence Journal, 5(1).

Berghe, V. and Hyung, J. (2011), Job satisfaction and job performance at the workplace, Research thesis

Deal, T.E. and Kennedy, A.A. (1982) Corporate Cultures-The Rites and Rituals of Corporate Life. Reading, MA: Addison.

Denison, D.R. (1990). Corporate Culture and Organisational Effectiveness. New York: Wiley.

Denison, D. R., and Mishra, A. K. (1995) toward a theory of organizational culture and effectiveness, Organization Science, 6(2), 204-23.

Dessler, G. (2009), a framework for Human Resource Management, Pearson Education India

Ehtesham, M. Muhammad. And Muhammad. (2011). Relationship between organizational culture and performance management practices: A case study of university in Pakistan, Journal of Competitiveness Issue, 4.

Gibson, Ivancevich and Donnely. (1995). Organizational: Behaviour, Structure, Process, Eeight, Binarupa Aksara, Jakarta.

Ghani, Ahmad, 2006, Pengaruh Gaya Kepemimpinan, Budaya Organisasi dan Motivasi Kerja Terhadapa Kinerja Karyawan Industri Kayu Olahan di Kota Makassar Sulawesi Selatan.Dissertation, Graduate Program of Brawijaya University, Malang. 
Hsu, P. Y. (2005). The research of the influence of cross-cultural on the job performance: The case on Philippine \& Thailand labor in the high-tech industry. Unpublished master's thesis, National Cheng Kung University, Taiwan.

Jex, S.M. (2002) Organizational Psychology: A Scientist-Practitioner Approach. John Wiley \& Sons, New York

Kotter, J. P. \& Heskett, J. L. (1992). Corporate culture and performance. New York: Free Press.

Kandula, S. R. (2006). Performance Management. New Delhi: Prentice-Hall of India private limited.

Mangkunegara, A.P. (2005). Human Resources Evaluation. Reflika Aditama, Bandung.

Mohamed I.A. \& Abukar A.A.S. (2013), the impact of organizational culture on employee's performance of Mogadishu Universities, Academic Research International, 4(6)

Nazir, N. \& Zamir, S. (2015), Impact of Organizational Culture on employee's performance, Industrial Engineering Letters, 5(9)

Olughor, R.J. (2014), the influence of organizational Culture on Firm's effectiveness, Journal of Business and Management, 6(1), 67-70

Ojo, O. (2009). Impact assessment of corporate culture on employee job: Journal of Business Intelligence, 2/2, 389-37.

Okta, K., Umar, N., Musadiq, A., \& Hamidah, N.Y. (2015), The Influence of Organizational Culture and Entrepreneurial Orientation on the Job Satisfaction, Organizational Commitment, and Employee's Performance, European Journal of Business and Management, 7(2)

Paschal \& Nizam Dr. (2016), Effects of organizational Culture on Employees Performance, International Journal of Accounting and Business Management, Vol.4 (No.1)

Prawirosentono and Suryadi. (2000). Employee Performance Policy, Yogyakarta, BPFE

Prasetya, A., and Kato, M. (2011). The Effect of Financial and Non-Financial Compensation to the Employee Performance, the 2nd International Research Symposium in Service Management. Yogyakarta, Indonesia.

Raka, I.B. 2003.Pengaruh Kepemimpinan, Budaya Organisasi dan Faktor Individu terhadap Perilaku Kerja dan Kinerja Organisasi pada Bank Nasional di Bali. Dissertation, Airlangga University, Surabaya

Ravasi, D. and Schultz, M. (2006). Responding to organizational identity threats: Exploring the role of organizational culture, Academy Management Journal, 49(3), 433-458

Schrodt, P. (2002). The relationship between organizational identification and organizational culture: Employee Perceptions of culture and identification in a retail sales organization, Communication Studies, 53(2), 18-202

Schein, E.H. (1992). Organizational Culture and Leadership, Jossey-Bass, San Francisco.

Sun, B. C. (2001). Public management. Taipei, Taiwan: Best Wise. Whitmore, John. 1997. Coaching for Performance: Growing People, Performance, and Purpose. Book bytes

Syauta, J.H, Troena, E.F \& Solimun, M.S. (2012), The influence of organizational culture, organizational commitment to job satisfaction and employee performance, International Journal of Business and Management Invention, 1(1), 69-76

Van den Berg P.T. \& Wilderom, C. (2004). Defining, Measuring and Company Organizational Cultures. Applied Psychology: International Association for Applied Psychology, S3 (4) $570-582$.

Whitmore, J. (1997). Coaching for performance. London: Nicholas Brealey Publishing

Williams, L. J., and Anderson, S. E. (1991). Job Satisfaction and Organizational Commitment as Predictors of Organizational Citizenship and in-role Behaviors. Journal of Management, 17(3), 601-617.

Zakari. Poku., M., Anash, K. O., \& Wilberforce, (2013). Organizational Culture and Organizational Performance, International Journal of Business, Humanities and Technology, 3(1) 